\title{
Synthesis and Characterization of an Alkoxythiazole-thiazolothiazole Semiconducting Polymer for Organic Solar Cells \\ Masahiko SAITO ${ }^{a, b}$ and Itaru OSAKA, ${ }^{a, b}$
}

\author{
a Emergent Molecular Function Research Group, RIKEN Center for Emergent Matter Science, \\ Wako, Saitama 351-0198, Japan \\ b Department of Applied Chemistry, Graduate School of Engineering, Hiroshima University, \\ Higashi-Hiroshima 739-8527, Japan \\ * Corresponding author: iosaka@hiroshima-u.ac.jp
}

\begin{abstract}
We report the synthesis and characterization of a new thiazolothiazole (TzTz)-based semiconducting polymer incorporating the alkoxythiazole unit in the polymer backbone (PTzTTz-BOoHD). The introduction of the alkoxythiazole unit in a thiophene-TzTz polymer (PTzBT-BOHD) lowered the LUMO energy level while keeping the HOMO energy level, resulting in a narrower bandgap. The solar cell with PTzTTz-BOoHD showed photoresponse in a wider spectral range $(\sim 740 \mathrm{~nm})$ compared to that with PTzBT-BOHD and with a thiophene-TzTz polymer having the alkoxy thiophene unit (PTzBT-BOoHD). Although the fill factor (FF) of the cell based on PTzTTz-BOoHD was lower than the cell based on PTzBT-BOHD and -BOoHD, the maximum PCE of the cell based on PTzTTz-BOoHD resulted in $6.2 \%$, which was comparable to and higher than the cell based on PTzBT-BOHD and -BOoHD, respectively. While PTzTTz-BOoHD showed good crystallinity in the polymer film, it was reduced in the film blended with $\mathrm{PC}_{61} \mathrm{BM}$, which is likely an origin of the drop of FF. As PTzTTz-BOoHD has more suitable electronic structures for solar cells such as a deep HOMO level and a narrow bandgap, compared to the other two polymers, we expect that PTzTTz-BOoHD would demonstrate higher PCE by further device optimization.
\end{abstract}

(c) The Electrochemical Society of Japan, All rights reserved.

Keywords : Organic Solar Cell, Semiconducting Polymer, Alkoxythiazole, Thiazolothiazole

\section{Introduction}

In the past decades, polymer-based organic solar cells (PSCs), in which the active layer typically consists of semiconducting polymers as p-type and fullerene derivatives as n-type, respectively have yielded power conversion efficiency (PCE) of over $10 \% .^{1-9}$ In order to improve the performance of PSCs, the semiconducting polymer must be tuned for its electronic structure, such as the bandgap $\left(E_{\mathrm{g}}\right)$, the highest occupied molecular orbital (HOMO) and the lowest unoccupied molecular orbital (LUMO) energy levels ( $E_{\mathrm{HOMO}}$ and $\left.E_{\mathrm{LUMO}}\right)$, since, in principle, small $E_{\mathrm{g}}$ offers high short-circuit current density $\left(J_{\mathrm{SC}}\right)$ and deep $E_{\mathrm{HOMO}}$ offers a high open-circuit voltage $\left(V_{\mathrm{OC}}\right)$. Semiconducting polymers consisting of an electron-rich and an electron-poor unit, which is called donor acceptor (D-A) polymers, are particularly attractive, as they offer facile tunability of electronic structures. ${ }^{10-13}$ In parallel, the performance of PSCs largely depend on the ordering structure of the semiconducting polymer, i.e. crystallinity and backbone orientation. ${ }^{4,14-20}$ Thus, the ordering structure must also be carefully controlled.

Among many D-A polymers studied so far, those with thiazlothiazole (TzTz) as the acceptor unit are an attractive system that provides highly ordered structures and thus high charge carrier mobilities. ${ }^{15,20-30}$ We have reported on a series of TzTz-based polymers with alkylthiophenes as the donor unit. ${ }^{15,20-23,31,32}$ One of the highest performing polymers was PTzBT-BOHD (Fig. 1a), which demonstrated quite high PCEs of $\sim 7.5 \%$ in conventional single-junction cells. ${ }^{20}$ However, the relatively narrow absorption range of $\sim 665 \mathrm{~nm}$ (wide $E_{\mathrm{g}}$ of ca. $1.8 \mathrm{eV}$ ) for the polymers limited the light harvesting property. Thus, broadening of the absorption range (narrowing of the $E_{\mathrm{g}}$ ) has been a large issue for the further improvement of the PSC performances. Therefore, in the previous work, we introduced the alkoxy group with electron-donating nature as the side chains of PTzBT backbone (PTzBT-BOoHD, Fig. 1a).
Although this successfully broadened the absorption range, the $E_{\mathrm{HOMO}}$ of the polymer was raised, which resulted in the drop of $V_{\mathrm{OC}}$ and hence PCEs. ${ }^{31}$

In this study, we introduced the alkoxythiazole unit (PTzTTzBOoHD) instead of the alkoxythiohene unit in order to reduce the $E_{\mathrm{g}}$ without raising the $E_{\mathrm{HOMO}}$ of PTzBT-BOHD. In fact, it was reported that the alkoxythiazole unit can reduce the $E_{\mathrm{g}}$ of the polymer similarly as in the case of the alkoxythiophene unit, but can afford a deep $E_{\text {HOMO }}$ similarly as in the case of the alkylthiophene unit. ${ }^{33} \mathrm{We}$ will show the synthesis of the polymer and discuss the properties, ordering structures, and PSC performance.

\section{Results and Discussion}

The synthetic route to the monomer consisting of the alkoxythiazole and TzTz unit and PTzTTz-BOoHD, in which the 2-hexyldecyl group was used as the alkyl moiety, is shown in Fig. 1b. First, alkoxythiazole (1) was formylated by the Vilsmeier reaction to give alkoxythiazole carboxaldehyde (2). The mixture of 2 and dithiooxiamide was heated at $180^{\circ} \mathrm{C}$ for 6 hours, which yielded the alkoxythiazole-TzTz compound (3). 3 was then dibrominated to provide Tz2Tz-oHD that is the monomer for polymerization. PTzTTz-BOoHD was synthesized by using Tz2TzoHD and the distannylated co-monomer consisting of alkylthiophene and $\mathrm{TzTz}$ (4) via the Stille coupling reaction using a microwave reactor. PTzTTz-BOoHD was soluble in warm chloroform $(\mathrm{CF})$ and chlorobenzene $(\mathrm{CB})$. The molecular weight of the polymers evaluated by high temperature gel permeation chromatography (GPC) at $140^{\circ} \mathrm{C}$ was $31 \mathrm{kDa}$ for $M_{\mathrm{n}}$ and $96 \mathrm{kDa}$ for $M_{\mathrm{w}}$.

To confirm the electronic effect of the alkoxythiazole unit, we carried out the cyclic voltammetry $(\mathrm{CV})$ for the monomer units, in which $\mathrm{TzTz}$ is sandwiched by alkylthiophenes (Tz2T-HD), alkoxythiophenes (Tz2T-oHD) and alkoxythiazoles (Tz2Tz-oHD) 
a

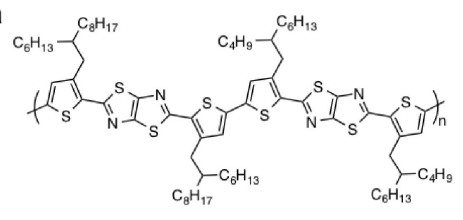

PTzBT-BOHD

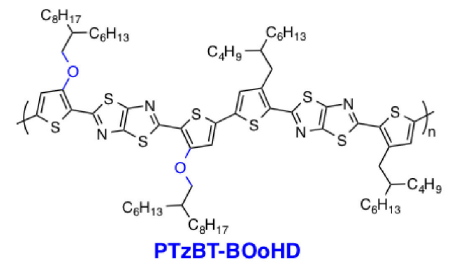

PTzBT-BOoHD

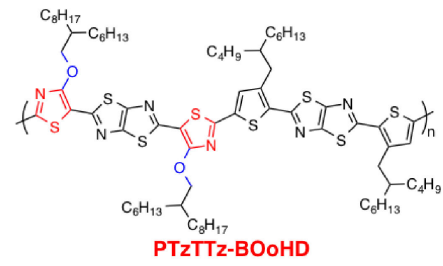

PTzTTz-BOoHD

b

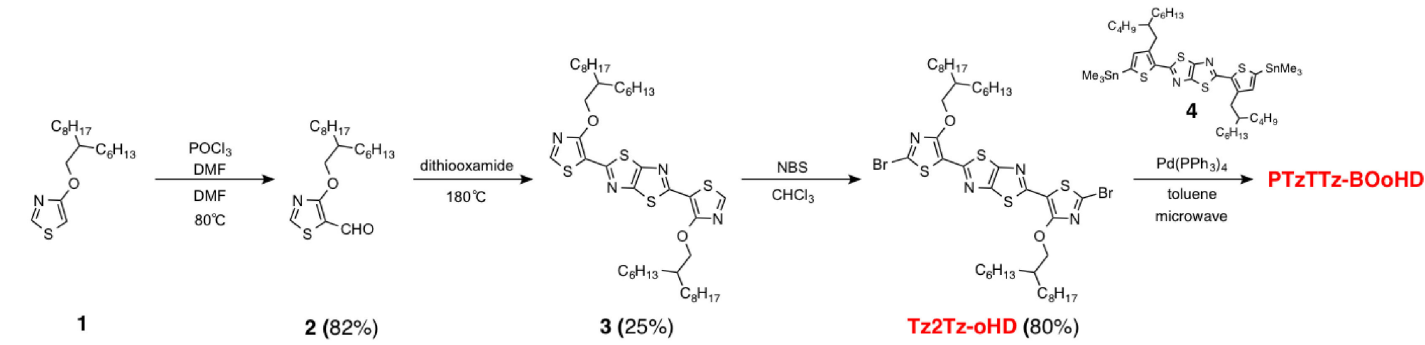

Figure 1. (Color online) (a) Chemical structure of the TzTz-based polymers (PTzBT-BOHD, PTzBT-BOoHD, and PTzTTz-BOoHD). (b) Synthetic route to PTzTTz-BOoHD.
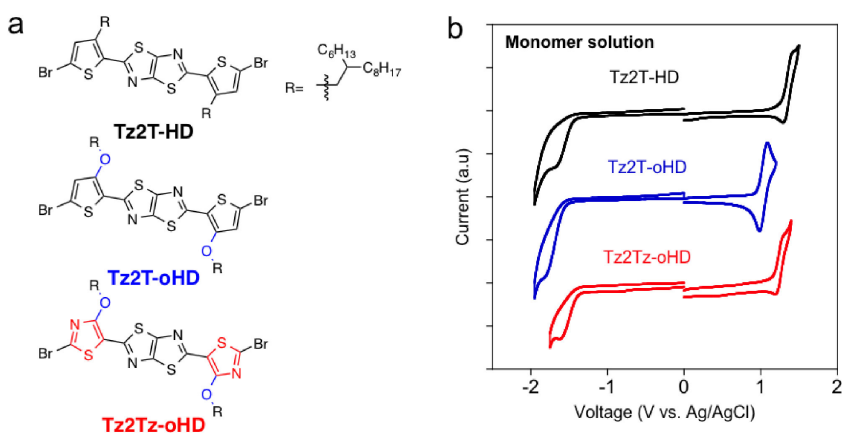

Figure 2. (Color online) (a) Chemical structure of the monomers (Tz2T-HD, Tz2T-oHD, and Tz2Tz-oHD), (b) cyclic voltammograms of the monomer units (Tz2T-HD, Tz2T-oHD, and Tz2Tz-oHD) in dichloromethane solution.

Table 1. Electronic properties of the monomer units and polymers.

\begin{tabular}{lcccc}
\hline & $\begin{array}{c}E_{\text {HOMO }} \\
(\mathrm{eV})^{\mathrm{a}}\end{array}$ & $\begin{array}{c}E_{\mathrm{LUMO}} \\
(\mathrm{eV})^{\mathrm{a}}\end{array}$ & $\begin{array}{c}E_{\mathrm{g}} \\
(\mathrm{eV})\end{array}$ & $\begin{array}{c}\lambda_{\text {edge }}(\mathrm{nm})^{\mathrm{b}} / \\
E_{\mathrm{g}}{ }^{\mathrm{opt}}(\mathrm{eV})\end{array}$ \\
\hline Tz2T-HD & -5.56 & -2.73 & 2.83 & \\
Tz2T-oHD & -5.28 & -2.62 & 2.66 & \\
Tz2Tz-oHD & -5.51 & -2.85 & 2.66 & \\
PTzBT-BOHD & -5.31 & -3.25 & 2.06 & $665 / 1.84$ \\
PTzBT-BOoHD & -5.20 & -3.26 & 1.94 & $725 / 1.71$ \\
PTzTTz-BOoHD & -5.39 & -3.43 & 1.96 & $735 / 1.69$ \\
\hline
\end{tabular}

${ }^{\mathrm{a}} E_{\mathrm{HOMO}} \mathrm{S}$ and $E_{\mathrm{LUMO}} \mathrm{S}$ were estimated from the onset oxidation and reduction potentials. ${ }^{\text {b }} \lambda_{\text {edge: }}$ absorption edge, $E_{\mathrm{g}}$ opt: bandgap calculated with $\lambda_{\text {edge. }}$

(Fig. 2a). Figure $2 \mathrm{~b}$ shows the cyclic voltammograms of the monomers measured in the dichloromethane solution. $E_{\mathrm{HOMO}}$ and $E_{\mathrm{LUMO}} \mathrm{S}$ of the Tz2T-HD, Tz2T-oHD, and Tz2Tz-oHD were estimated from the onset oxidation and reduction potentials. $E_{\mathrm{HOMO}}$ of Tz2Tz-oHD $(-5.51 \mathrm{eV})$ was $0.3 \mathrm{eV}$ deeper than that of Tz2ToHD $(-5.28 \mathrm{eV})$ and almost the same with that of Tz2T-HD $(-5.56 \mathrm{eV})$ (Table 1). $E_{\mathrm{Lumo}}$ of the Tz2Tz-oHD was lower $(-2.85 \mathrm{eV})$ than that of both Tz2T-oHD $(-2.62 \mathrm{eV})$ and Tz2T-HD $(-2.73 \mathrm{eV})$. These results indicate that the alkoxythiazole unit has stronger electron deficiency relative to alkylthiophene and alkoxythiophene. $E_{\mathrm{HOMO}} \mathrm{S}$ and $E_{\mathrm{LUMO}} \mathrm{S}$ of the polymers (PTzBT-BOHD, PTzBT-BOoHD, and PTzTTz-BOoHD) were also estimated from
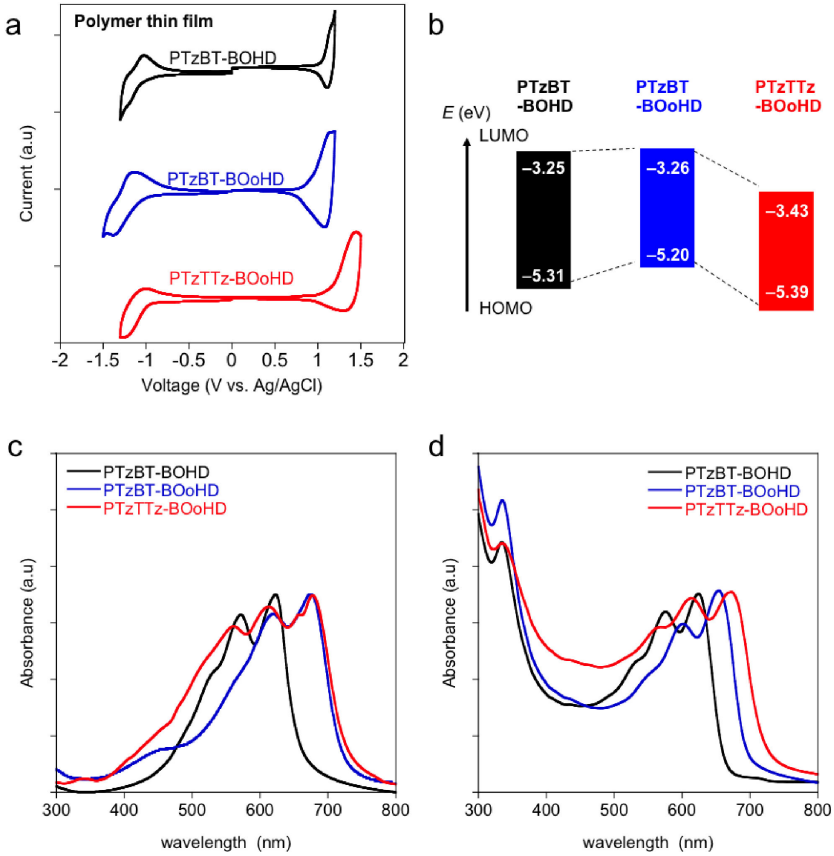

Figure 3. (Color online) (a) Cyclic voltammograms of the polymer thin films (PTzBT-BOHD, PTzBT-BOoHD, and PTzTTz$\mathrm{BOoHD}$ ) in acetonitrile solution, (b) energy diagrams of polymers. (c, d) UV-vis absorption spectra of the polymer thin films (c) and polymer/PCBM blend films (d).

CV using the thin films (Fig. 3a) and were summarized in Table 1. $E_{\text {HOMO }}$ of PTzTTz-BOoHD was found to be $-5.39 \mathrm{eV}$, which was deeper than that of both PTzBT-BOHD $(-5.31 \mathrm{eV})$ and PTzBTBOoHD $(-5.20 \mathrm{eV}) . E_{\mathrm{LuMO}}$ of PTzTTz-BOoHD $(-3.43 \mathrm{eV})$ was also deeper than that of PTzBT-BOHD $(-3.25 \mathrm{eV})$ and PTzBTBOoHD $(-3.26 \mathrm{eV})$ (Fig. 3b). The results in the polymers agree well with the results in the monomers.

UV-vis absorption spectra of the polymer and polymer/PCBM thin films are shown in Figs. $3 c$ and $3 d$. As expected from the results in $\mathrm{CV}$, PTzTTz-BOoHD exhibited absorption spectra with the absorption edge $\left(\lambda_{\text {edge }}=735 \mathrm{~nm}\right)$ similar to that of PTzBTBOoHD $\left(\lambda_{\text {edge }}=725 \mathrm{~nm}\right)$ and red-shifted compared to that of PTzBT-BOHD $\left(\lambda_{\text {edge }}=665 \mathrm{~nm}\right)($ Table 2$) . E_{\mathrm{g}}$ of PTzTTz-BOoHD was thus calculated to be $1.69 \mathrm{eV}$, which is similar to PTzBT-BOHD and narrower than PTzTTz-BOoHD. In the polymer/PCBM blend film, the absorption edge of PTzBT-BOoHD was red-shifted from 
Table 2. Photovoltaic properties of the solar cells based on PTzBT-BOHD, -BOoHD, and PTzTTzBOoHD.

\begin{tabular}{lcccccc}
\hline \multicolumn{1}{c}{ Polymer } & $\begin{array}{c}J_{\mathrm{SC}} \\
\left(\mathrm{mA} \mathrm{cm}^{-2}\right)\end{array}$ & $\begin{array}{c}J_{\mathrm{SC}} \mathrm{calc}^{-2} \\
\left(\mathrm{~mA} \mathrm{~cm}^{-2}\right)^{\mathrm{a}}\end{array}$ & $\begin{array}{c}V_{\mathrm{OC}} \\
(\mathrm{V})\end{array}$ & $\mathrm{FF}$ & $\begin{array}{c}\mathrm{PCE}_{\max }\left[\mathrm{PCE}_{\text {ave }}\right] \\
(\%)^{\mathrm{a}}\end{array}$ & $\begin{array}{c}\mu_{\mathrm{SCLC}} \\
\left(\mathrm{cm}^{2} / \mathrm{Vs}\right)\end{array}$ \\
\hline PTzBT-BOHD & 10.0 & 10.1 & 0.88 & 0.76 & $6.7[6.4]$ & $2.0-4.0 \times 10^{-4}$ \\
PTzBT-BOoHD & 9.5 & 9.1 & 0.70 & 0.74 & $4.9[4.7]$ & $3.0-4.4 \times 10^{-4}$ \\
PTzTTz-BOoHD & 11.2 & 11.1 & 0.84 & 0.66 & $6.2[6.0]$ & $0.3-0.9 \times 10^{-4}$ \\
\hline
\end{tabular}

${ }^{\mathrm{a}} J_{\mathrm{SC}}$ was estimated from EQE spectra.
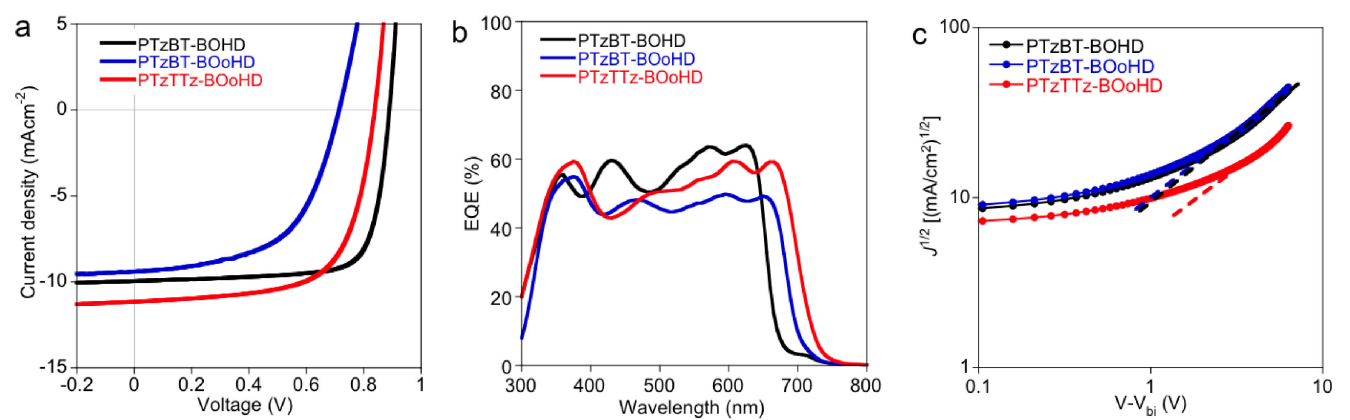

Figure 4. (Color online) $J-V$ curves (a), EQE spectra (b), and hole-only devices (c) of the solar cells based on PTzBT-BOHD, -BOoHD, and PTzTTz-BOoHD.

polymer-neat film $\left(\lambda_{\text {edge }}=705 \mathrm{~nm}\right)$. Overall, the introduction of alkoxythiazole instead of alkylthiophene and alkoxythiophene indeed provided the better suited electronic structure for PSCs.

We fabricated inverted cells with the configuration of $\mathrm{ITO} / \mathrm{ZnO} /$ polymer:[6,6]-phenyl-C61-butyric acid methyl ester $\left(\mathrm{PC}_{61} \mathrm{BM}\right) /$ $\mathrm{MoO}_{x} / \mathrm{Ag}$. The optimum polymer to $\mathrm{PC}_{61} \mathrm{BM}$ weight ratio was 1:2 for all the polymers. The solution of the polymer and $\mathrm{PC}_{61} \mathrm{BM}$ in chlorobenzene $(\mathrm{CB})$ was deposited by spin coating, which gave the active layer film with the thickness of ca. $200 \mathrm{~nm}$. The current density $(J)$-voltage $(V)$ curves and the external quantum efficiency (EQE) spectra of the cells under 1 sun of simulated AM 1.5G solar irradiation $\left(100 \mathrm{~mW} / \mathrm{cm}^{2}\right)$ are displayed in Figs. $4 \mathrm{a}$ and $3 \mathrm{~b}$, respectively, and photovoltaic parameters are summarized in Table 2. The PTzTTz-BOoHD cell gave higher $J_{\mathrm{SC}}$ of $11.2 \mathrm{~mA} / \mathrm{cm}^{2}$ than the PTzBT-BOHD cell $\left(10.0 \mathrm{~mA} / \mathrm{cm}^{2}\right)$ and the PTzBT-BOoHD-based cell $\left(9.5 \mathrm{~mA} / \mathrm{cm}^{2}\right)$. The difference of $J_{\mathrm{SC}}$ was consistent with the EQE spectra (Fig. 4b). The PTzTTz-BOoHD cell showed photoresponse in a wider spectral range compared to the PTzBT-BOHD and PTzBT-BOoHD cells. It is also noted that the EQE value at the polymer absorption range was higher for PTzTTz-BOoHD than for PTzBT-BOoHD. $V_{\mathrm{OC}}$ of the PTzTTz-BOoHD cells $(0.84 \mathrm{~V})$ was $0.1 \mathrm{~V}$ higher than that of the PTzBT-BOoHD cells $(0.70 \mathrm{~V})$, which reflects the difference in $E_{\mathrm{HOMO}}$. However, despite the fact that $E_{\text {Hомо }}$ of PTzTTz-BOoHD was deeper than that of PTzBT-BOHD by $0.1 \mathrm{eV}, V_{\mathrm{OC}}$ of the PTzTTz-BOoHD cells were slightly decreased by $0.03-0.04 \mathrm{~V}$ compared to the PTzBT-BOHD cells $(0.88 \mathrm{~V})$. The origin of the $V_{\mathrm{OC}}$ drop is yet unknown. The PTzTTz-BOoHD cell showed lower fill factor (FF) of 0.66 than of the cells with PTzBTBOHD (0.76) and PTzBT-BOoHD (0.74). As a result, the PCE of the PTzTTz-BOoHD-based cell $(6.2 \%)$ were almost comparable to that of the PTzBT-BOHD cells $(6.7 \%)$ and much higher than that of the PTzBT-BOoHD cells $(4.9 \%)$. We also investigated the charge transport property of the polymer/PCBM films by using hole-only devices (ITO/PEDOT:PSS/(polymer/ $/ \mathrm{PC}_{61} \mathrm{BM}$ ) $/ \mathrm{MoO}_{x} / \mathrm{Ag}$ ) where the p:n ratio was 1:2. (Fig. 4c). Hole mobilities $\left(\mu_{\mathrm{SCLC}}\right)$ were calculated by using the space-charge-limited current (SCLC) model. The $\mu_{\text {SCLC }}$ of the PTzTTz-BOoHD film $\left(0.3-0.9 \times 10^{-4} \mathrm{~cm}^{2} / \mathrm{Vs}\right)$ was lower than that of PTzBT-BOHD $\left(2.0-4.0 \times 10^{-4} \mathrm{~cm}^{2} / \mathrm{Vs}\right)$ and
PTzBT-BOoHD $\left(3.0-4.4 \times 10^{-4} \mathrm{~cm}^{2} / \mathrm{Vs}\right)$ film. Thus, we assume that this is one of the reasons for the drop of FF in the PTzTTzBOoHD cell.

To further understand the photovoltaic performance of the cells, we investigated the ordering structure of the polymers by grazing incidence X-ray diffraction (GIXD) study. The two-dimensional (2D) GIXD patterns of the polymer neat films and polymer $/ \mathrm{PCB}_{61} \mathrm{M}$ blend films on the ITO/ZnO substrate are shown in Figs. 5a-h. In polymer neat films, although the diffraction corresponding to the lamellar structure, $(100),\left(q \approx 0.25 \AA^{-1}\right)$ appeared on both the $q_{\mathrm{z}}$ and $q_{\mathrm{xy}}$ axis, the diffraction corresponding to the $\pi-\pi$ stacking structure, $(010),\left(q \approx 1.65-1.70 \AA^{-1}\right)$ appeared only on the $q_{\mathrm{z}}$ axis for all polymers. This indicates that these polymers mainly formed the faceon orientation that is desirable for OPV devices. ${ }^{20}$ The $\pi-\pi$ stacking distances $\left(d_{\pi}\right)$ of PTzBT-BOHD, -BOoHD, and PTzTTz-BOoHD estimated from the polymer neat films were $3.54,3.59$, and $3.54 \AA$, respectively, which were mostly preserved in the blend films. We further evaluated the full width at half-maximaun (FWHM) for the (010) peak along the $\sim q_{z}$ axis. FWHM of PTzBT-BOHD, -BOoHD, and PTzTTz-BOoHD were $019,0.16$, and $0.16 \AA^{-1}$ in the polymer neat films, with which the coherence length for the polymer crystallite were calculated to be $33,39,39 \AA$, respectively, by using the Scherrer equation $(2 \pi / \mathrm{FWHM}){ }^{34}$ This suggests that the crystallinity of the polymers is almost the same. However, FWHM for the blend films were $0.26,0.24$, and $0.35 \AA^{-1}$, which correspond to the coherence length of 24,26 , and $18 \AA$, respectively, suggesting that the crystallinity of PTzTTz-BOoHD was reduced. This is in good agreement with the fact that the $\mu_{\mathrm{SCLC}}$ of PTzTTz-BOoHD was lower than the others. Thus, the lower crystallinity in the blend film can be one of the main reasons that the PTzTTz-BOoHD cell showed lower FF than the others. We also investigated the morphology of the blend films by the atomic force microscopy (AFM) (Figs. 6a-c). Seemingly, all polymers formed similar phase-separated structures and the surface roughness estimated by the root mean square (rms) values were also similar; rms for the blend films of PTzTTz-BOoHD, PTzBT-BOHD, and PTzBT-BOoHD were 1.59, 2.01, and 1.61, respectively. This implies that the morphology should not be a critical reason for the difference in the PSC performance. 

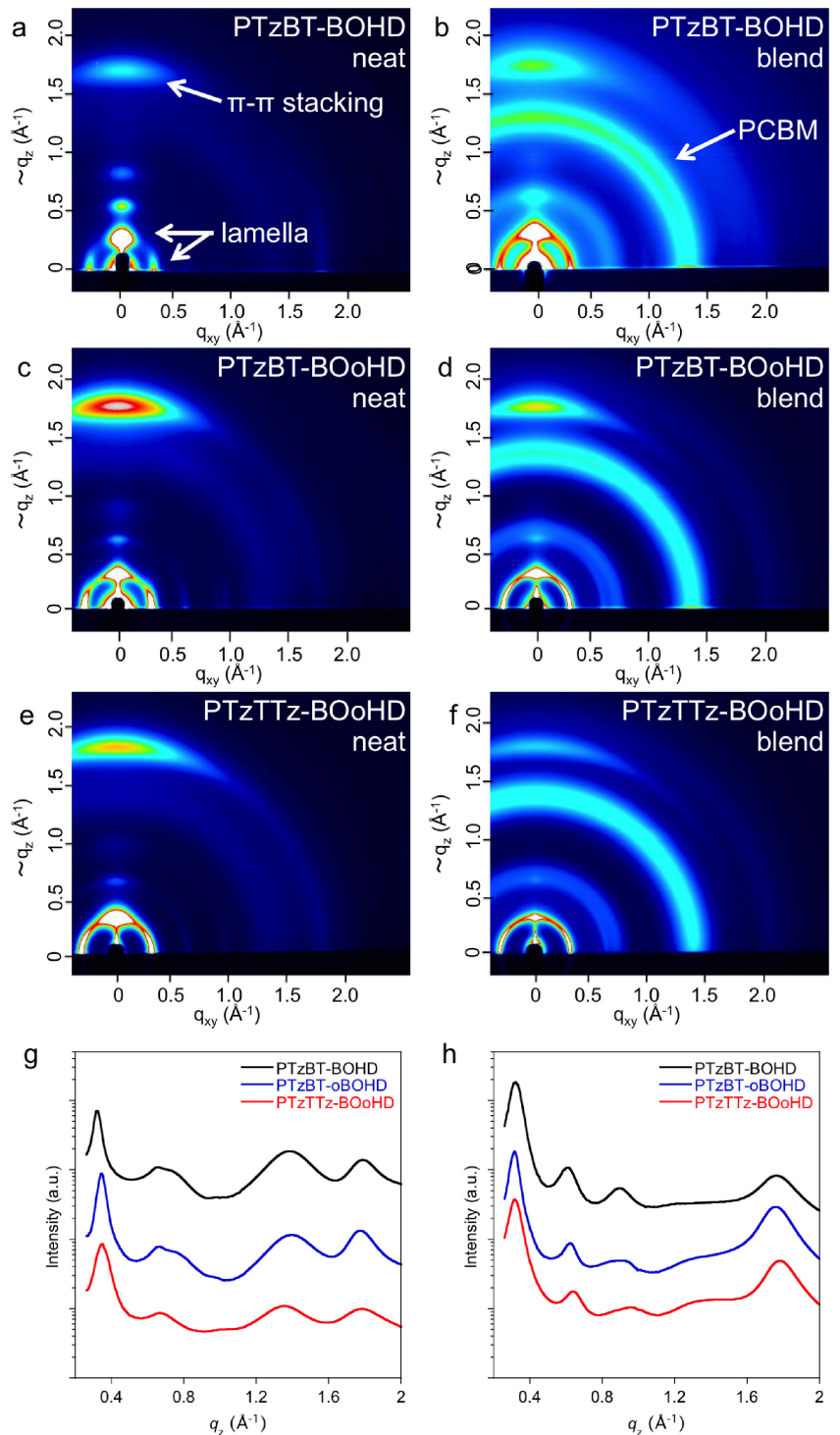

Figure 5. (Color online) (a-g) 2D GIXD patterns of the polymer neat film $(\mathrm{a}, \mathrm{c}, \mathrm{e})$ and the polymer $/ \mathrm{PC}_{61} \mathrm{BM}$ blend films $(\mathrm{b}, \mathrm{d}, \mathrm{f})$ : (a, b) PTzBT-BOHD, (c, d) PTzBT-BOoHD, (e, f) PTzTTzBOoHD. (g, h) Cross-section profiles of the polymer neat films (g) and polymer/PCBM blend films (h), cut from the 2D GIXD patterns along the $q_{\mathrm{z}}$ axis.

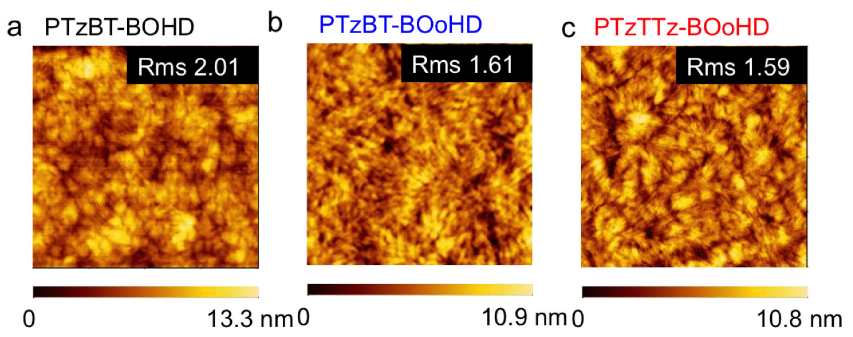

Figure 6. (Color online) AFM images of polymer/PCBM blend film PTzBT-BOHD, PTzBT-BOoHD, and PTzTTz-BOoHD.

In summary, we have synthesized and characterized a new semiconducting polymer consisting of thiazolothiazole, alkylthiophene, and alkoxythiazole, namely PTzTTz-BOoHD. As expected, the introduction of the alkoxythiazole unit instead of alkoxythiophene in the polymer backbone lowered $E_{\text {НОмо }}$ while keeping $E_{\mathrm{g}}$. Consequently, the PTzTTz-BOoHD cell showed photoresponse in the spectral range similar to the PTzBT-BOoHD cell and wider than the PTzBT-BOHD cell. Furthermore, the PTzTTz-BOoHD cell showed relatively high $V_{\mathrm{OC}}$ of $0.84 \mathrm{~V}$, which was mostly much higher than the PTzBT-BOoHD cell. Although FF of the PTzTTzBOoHD cell was lower than the PTzBT-BOHD and -BOoHD cells, overall PCE of the PTzTTz-BOoHD cell was $6.2 \%$, which was comparable to the PTzBT-BOHD cell and much higher than the PTzBT-BOoHD cell. We assume that the main reason for the lower FF was the reduced crystallinity of PTzTTz-BOoHD in the blend film. However, as PTzTTz-BOoHD had similarly high crystallinity to the other polymers in the polymer neat film, the crystallinity in the blend film can possibly be improved by controlling the fabrication conditions, which would lead to the higher PCE.

\section{Experimental}

\subsection{Synthesis}

4-((2-hexyldecyl)oxy)-thiazole, ${ }^{32}$ 2,5-bis[3-(2-butyloctyl)-5-(trimethylstannyl)thiophen-2-yl] thiazolo[5,4- $d]$ thiazole, ${ }^{20}$ 2,5-bis[3-(2hexyldecyl)-5-bromothiophen-2-yl] thiazolo[5,4- $d]$ thiazole ${ }^{20} \quad 2,5$ bis[3-((2-hexyldecyl)oxy)-5-bromothiophen-2-yl] thiazolo[5,4- $d$ ] thiazole $^{31}$ were synthesized according to the published procedure. Toluene was purified by a Glass Contour Solvent System prior to use.

4-((2-Hexyldecyl)oxy)thiazole-5-carboxaldehyde (2)

To a solution of anhydrous DMF $(10 \mathrm{~mL})$ and $\mathrm{POCl}_{3}(0.53 \mathrm{~mL}$, $5.76 \mathrm{mmol}), 3-((2$-hexyldecyl)oxy)thiazole (1) $(1.02 \mathrm{~g}, 4.80 \mathrm{mmol})$ in $2 \mathrm{~mL}$ of DMF was added dropwise over the period of 5 minutes at $0^{\circ} \mathrm{C}$ under nitrogen atmosphere. Then, the reaction mixture was stirred for 90 minutes at $70^{\circ} \mathrm{C}$. The mixture was poured into ice water and then slowly neutralized with $10 \% \mathrm{NaOH}$ solution $(20 \mathrm{~mL})$. The aqueous layer was extracted with $\mathrm{CHCl}_{3}(3 \times 50 \mathrm{~mL})$, and the combined organic layer was dried over anhydrous $\mathrm{Na}_{2} \mathrm{SO}_{4}$. After the removal of solvents, the crude mixture was purified by column chromatography on silica gel ( $20 \%$ ethyl acetate in hexane) to give 2 as a colorless oil. $(1.0 \mathrm{~g}, 86 \%)$. HRMS Calcd for $\mathrm{C}_{20} \mathrm{H}_{35} \mathrm{NO}_{2} \mathrm{~S}$ $[\mathrm{M}+\mathrm{H}]^{+}:$354.24668. Found: 354.24661. ${ }^{1} \mathrm{H}-\mathrm{NMR}\left(\mathrm{CDCl}_{3}\right) \sigma 9.98$ $(\mathrm{s}, 1 \mathrm{H}), 8.77(\mathrm{~s}, 1 \mathrm{H}), 4.42(\mathrm{~d}, J=6.0 \mathrm{~Hz}, 2 \mathrm{H}), 1.84-1.82(\mathrm{~m}, 1 \mathrm{H})$, $1.39-1.32(\mathrm{~m}, 16 \mathrm{H}), 0.91-0.88(\mathrm{~m}, 6 \mathrm{H}) ;{ }^{13} \mathrm{C}-\mathrm{NMR}\left(\mathrm{CDCl}_{3}\right) \sigma 189.0$, 159.3, 157.4, 145.9, 110.4, 38.4, 32.1, 31.7, 31.2, 30.9, 30.2, 29.7, $29.6,29.3,26.7,14.1$.

2,5-Bis[4-((2-hexyldecyl)oxy)thiazole-5-yl]thiazolo[5,4- $d$ thiazole (3)

A mixture of dithiooxamide $(1.1 \mathrm{~g}, 9.2 \mathrm{mmol})$ and $2(6.0 \mathrm{~g}$, $20.2 \mathrm{mmol})$ was heated for $6 \mathrm{~h}$ at $200^{\circ} \mathrm{C}$. The crude product was purified by column chromatography on silica gel $(20 \%$ chloroform in hexane), and followed by recrystallization from hexane, which gave the pure product as a yellow solid (1.8 g, 29\%). HRMS Calcd for $\mathrm{C}_{42} \mathrm{H}_{68} \mathrm{~N}_{4} \mathrm{O}_{2} \mathrm{~S}_{4}[\mathrm{M}+\mathrm{H}]^{+}$: 789.430334. Found: 789.430330 . ${ }^{1} \mathrm{H}-\mathrm{NMR}\left(\mathrm{CDCl}_{3}\right) \sigma 8.57(\mathrm{~s}, 2 \mathrm{H}), 4.51(\mathrm{~d}, J=6.0 \mathrm{~Hz}, 4 \mathrm{H}), 1.84$ $1.82(\mathrm{~m}, 2 \mathrm{H}), 1.39-1.32(\mathrm{~m}, 32 \mathrm{H}), 0.91-0.88(\mathrm{~m}, 12 \mathrm{H}) ;{ }^{13} \mathrm{C}-$ $\operatorname{NMR}\left(\mathrm{CDCl}_{3}\right) \sigma 159.4,157.5,150.5,135.2,110.1,38.2,32.0,31.9$, $31.3,30.5,29.73,29.70,29.4,26.9,14.2$.

2,5-Bis[2-bromo-4-((2-hexyldecyl)oxy)thiazole-5-yl]thiazolo[5,4- $d$ ]thiazole (Tz2Tz-oHD)

To a solution of $\mathbf{3}(1.5 \mathrm{~g}, 2.2 \mathrm{mmol})$ in $\mathrm{CHCl}_{3}(50 \mathrm{~mL})$, a solution of NBS ( $870 \mathrm{mg}, 4.9 \mathrm{mmol})$ in $\mathrm{CHCl}_{3}(20 \mathrm{~mL})$ was added dropwise, and was stirred for $10 \mathrm{~min}$ at r.t. Then, the reaction solution was further stirred for 5 hours at $60^{\circ} \mathrm{C}$. The reaction solution was washed with water and brine, and the organic layer was concentrated. The crude product was purified by column chromatography on silica gel ( $20 \%$ chloroform in hexane) and recrystallized from hexane to give pure product as yellow solids $(1.57 \mathrm{~g}, 85 \%)$. HRMS Calcd for $\mathrm{C}_{42} \mathrm{H}_{68} \mathrm{Br}_{2} \mathrm{~N}_{4} \mathrm{O}_{2} \mathrm{~S}_{4}[\mathrm{M}+\mathrm{H}]^{+}$: 945.25136. Found: 945.25132. ${ }^{1} \mathrm{H}-$ $\operatorname{NMR}\left(\mathrm{CDCl}_{3}\right) \sigma 4.45(\mathrm{~d}, J=6.0 \mathrm{~Hz}, 4 \mathrm{H}), 1.86-1.82(\mathrm{~m}, 2 \mathrm{H}), 1.39$ $1.32(\mathrm{~m}, 32 \mathrm{H}), 0.91-0.88(\mathrm{~m}, 12 \mathrm{H}) ; \sigma 159.9,159.5,153.2,137.2$, $110.9,38.4,31.9,32.1,31.7,31.1,30.2,29.7,29.5,29.2,26.1,13.9$. 


\subsection{PTzTTz-BOoHD}

To a reaction tube equipped with a stirring bar, 2,5-bis[3-(2butyloctyl)-5-(trimethylstannyl)thiophen-2-yl]thiazolo[5,4- $d]$ thiazole (4) $(0.10 \mathrm{mmol})$, Tz2Tz-oHD $(0.10 \mathrm{mmol}), \mathrm{Pd}\left(\mathrm{PPh}_{3}\right)_{4}(1.8 \mathrm{mg}$, $0.002 \mathrm{mmol})$, and toluene $(5 \mathrm{ml})$ were added. Then, the tube was purged with argon and sealed. The reaction tube was set into a microwave reactor and heated to $140^{\circ} \mathrm{C}$ for $30 \mathrm{~min}$. After cooling to r.t, the reaction solution was poured into $200 \mathrm{~mL}$ of methanol containing $5 \mathrm{~mL}$ of hydrochloric acid, and stirred for 5 hours. Then the precipitated solid was subjected to the sequential Soxhlet extraction with methanol and hexane to remove low molecular weight fractions. The residue was then extracted with chloroform, and reprecipitated in $200 \mathrm{~mL}$ of methanol to yield dark blue solids (yield $=88 \%)$.

\section{Instrumentation}

NMR spectra were measured in deuterated chloroform with a JNM-ECS-400 spectrometer. Molecular weight of the polymers was evaluated by a high-temperature GPC $\left(140^{\circ} \mathrm{C}\right)$, TOSOH HLC$8121 \mathrm{GPC} / \mathrm{HT}$, using DCB as the eluent and polystyrene standard. Cyclic voltammetry was carrid out with an ALS Electrochemical Analyzer Model 612D by using a three-electrode system consisting of a platinum disk working electrole, a platinum wire counter electrode, and an $\mathrm{Ag} / \mathrm{AgCl}$ reference electronde. Monomers $(0.1 \mathrm{mM})$ were measued in dichloromethane solution containing tetrabutylammonium hexafluorophosphate $(0.1 \mathrm{M})$ and polymer thin films were measued as thin films in acetonitrile solution containing tetrabutylammonium hexafluorophosphate $(0.1 \mathrm{M})$ at the scan rate of $10 \mathrm{mV} \mathrm{s}^{-1}$. UV-vis absorption spectra were measured using a Shimadzu UV-3600 spectrometer. The grazing incidence X-ray diffraction (GIXD) experiments were conducted at the SPring- 8 on the beamline BL46XU. The sample was irradiated at a fixed incident angle on the order of $0.12^{\circ}$ through a Huber diffractometer with the X-ray energy of $12.39 \mathrm{keV}(\lambda=1 \AA)$. Two-dimensional (2D) GIXD patterns were recorded with a 2D image detector (Pilatus $300 \mathrm{~K})$. Samples for the X-ray measurements were prepared by spin-coating the polymer and the polymer $/ \mathrm{PC}_{61} \mathrm{BM}$ on the ITO/ $\mathrm{ZnO}$ substrate with the same conditions as the OPV fabrications. Dynamic force-mode atomic force microscopy study was carried out on a Nanocute scanning probe microscope system (SII Nanotechnology, Inc.).

\section{Solar Cell Fabrication and Measurement}

Patterned ITO substrates were purchased from Atsugi Micro. For the inverted cell fabrication, patterned ITO substrates were first precleaned sequentially by sonicating in a detergent bath, de-ionized water, acetone, and isopropanol at room temperature, and in boiled isopropanol each for $10 \mathrm{~min}$, and then baked at $120^{\circ} \mathrm{C}$ for 10 minutes in air. The substrates were then subjected to a UV/ozone treatment at $\mathrm{rt}$ for $20 \mathrm{~min}$. $\mathrm{ZnO}$ layer was prepared by spin-coating (at $5000 \mathrm{rpm}, 30 \mathrm{sec}$ ) a precursor solution prepared from zinc acetate dehydrate $(0.27 \mathrm{~g})$ and ethanolamine $(0.07 \mathrm{~mL})$ in $2.5 \mathrm{~mL}$ of 2methoxyethanol. $\mathrm{ZnO}$ substrates were immediately baked at $170^{\circ} \mathrm{C}$ for $30 \mathrm{~min}$ in air, and then rinsed with aceton, isopropanol and boiled isopropanol for 10 minutes. The photoactive layer was deposited in a glove box (KOREA KIYON, KK-011AS-EXTRA), by spin coating a chlorobenzene solution containing 3-6g/L of the polymer sample with respective amount of $\mathrm{PC}_{61} \mathrm{BM}$, at $600 \mathrm{rpm}$ for $20 \mathrm{sec}$, in which the solution was kept heated at $100^{\circ} \mathrm{C}$. The thin films were transferred into a vacuum evaporator (ALS Technology, E-100J) connected to the glove box, and the $\mathrm{MoO}_{x}$ layer $(7.5 \mathrm{~nm})$ and then the Ag layer $(100 \mathrm{~nm})$ were deposited sequentially. The active area of the cells was $0.16 \mathrm{~cm}^{2} . J-V$ characteristics of the cells were measured using a Keithley 2400 source-measure unit in nitrogen atmosphere under the 1 sun (AM1.5G) condition using a solar simulator (SAN-EI Electric, XES-40S1). The light intensity was calibrated with a reference PV cell (KONICA MINOLTA AK100 certified at National Institute of Advanced Industrial Science and Technology, Japan). EQE spectra were measured with a Spectral Response Measuring System (SOMA OPTICS, S-9241). More than 10 different substrates (four active areas each) were made and measured to collect the photovoltaic properties. The thickness of the active layer was measured with an AlphaStep D-100 surface profiler (KLA Tencor).

\section{Hole-only Device Fabrication}

For hole-only devices, the pre-cleaned ITO substrates were coated with PEDOT:PSS by spin-coating $(5000 \mathrm{rpm}$ for $30 \mathrm{~s}$, thickness of $\sim 30 \mathrm{~nm})$. The polymer $/ \mathrm{PC}_{61} \mathrm{BM}(1: 2 \mathrm{wt} / \mathrm{wt})$ blend film was then spin-coated as described above. The thin films were transferred into a vacuum evaporator connected to the glove box, and $\mathrm{MoO}_{x}(7.5 \mathrm{~nm})$ and $\mathrm{Ag}(100 \mathrm{~nm})$ were deposited sequentially through a shadow mask. The $J-V$ characteristics were measured in the range of $0-7 \mathrm{~V}$ using a Keithley 2400 source measure unit under nitrogen atmosphere in the dark, and the mobility was calculated by fitting the $J-V$ curves to a space charge limited current model described by

$$
J=(8 / 9) \varepsilon_{\mathrm{r}} \varepsilon_{0} \mu\left(\mathrm{V}^{2} / \mathrm{L}^{3}\right)
$$

where $\varepsilon_{\mathrm{r}}$ is the dielectric constant of the polymer, $\varepsilon_{0}$ is the permittivity of free space, $\mu$ is the mobility, $V=V_{\text {appl }}-V_{\mathrm{bi}}$, where $V_{\text {appl }}$ is the applied voltage to the device and $V_{\mathrm{bi}}$ is the built-in voltage due to the difference in workfunction of the two electrodes (determined to be $0.1 \mathrm{~V}$ ), and $L$ is the polymer thickness. The dielectric constant $\varepsilon_{\mathrm{r}}$ is assumed to be 3 , which is a typical value for semiconducting polymers.

\section{Acknowledgments}

This work was supported by the Advanced Low Carbon Technology Research and Development Program (ALCA) from JST and JSPS KAKENHI (Grant No. 16H04196). 2D GIXD experiments were performed at the BL46XU of SPring- 8 with the approval of the Japan Synchrotron Radiation Research Institute (JASRI) (Proposal No. 2016A1768). The authors thank Dr. K. Takimiya for his support on conducting this work. The authors thank Dr. T. Koganezawa (JASRI) for the support on 2D GIXD measurements.

\section{References}

1. Y. Lang, Z. Xu, J. Xia, S.-T. Tsai, Y. Wu, G. Li, C. Ray, and L. Yu, Adv. Mater, 22, E135 (2010).

2. H.-C. Chen, Y.-H. Chen, C.-C. Liu, Y. C. Chien, S.-W. Chou, and P.-T. Chou, Chem. Mater, 24, 4766 (2012).

3. C. Cabanetos, A. E. Labban, J. A. Bartelt, J. D. Douglas, W. R. Mateker, J. M. J. Fréchet, M. D. McGehee, and P. M. Beaujuge, J. Am. Chem. Soc., 135, 4656 (2013).

4. I. Osaka, T. Kakara, N. Takemura, T. Koganezawa, and K. Takimiya, J. Am. Chem. Soc., 135, 8834 (2013).

5. L. Ye, S. Zhang, W. Zhao, H. Yao, and J. Hou, Chem. Mater., 26, 3603 (2014)

6. Y. Liu, J. Zhao, Z. Li, C. Mu, W. Ma, H. Hu, K. Jiang, H. Lin, H. Ade, and H. Yan, Nat. Commun., 5, 5293 (2014).

7. V. Vohra, K. Kawashima, T. Kakara, T. Koganezawa, I. Osaka, K. Takimiya, and H. Murata, Nat. Photonics, 9, 403 (2015).

8. J. Zhao, Y. Li, G. Yang, K. Jiang, H. Lin, H. Ade, W. Ma, and H. Yan, Nat. Energy, 1, 15027 (2016).

9. K. Kawashima, T. Fukuhara, Y. Suda, Y. Suzuki, T. Koganezawa, H. Yoshida, H. Ohkita, I. Osaka, and K. Takimiya, J. Am. Chem. Soc., 138, 10265 (2016).

10. D. Mühlbacher, M. Scharber, M. Morana, Z. Zhu, D. Waller, R. Gaudiana, and C. Brabec, Adv. Mater., 18, 2884 (2006)

11. P.-L. T. Boudreault, A. Najari, and M. Leclerc, Chem. Mater., 23, 456 (2011).

12. A. Facchetti, Chem. Mater, 23, 733 (2011). 
13. P. M. Braujuge and J. M. J. Fréchet, J. Am. Chem. Soc., 133, 20009 (2011).

14. C. Piliego, T. W. Holcombe, J. D. Douglas, C. H. Woo, P. M. Beaujuge, and J. M. J. Fréchet, J. Am. Chem. Soc., 132, 7595 (2010).

15. I. Osaka, M. Saito, H. Mori, T. Koganezawa, and K. Takimiya, Adv. Mater, 24, 425 (2012).

16. A. T. Yiu, P. M. Beaujuge, O. P. Lee, C. H. Woo, M. F. Toney, and J. M. J. Fréchet, J. Am. Chem. Soc., 134, 2180 (2012).

17. L. Yang, J. R. Tumbleston, H. Zhou, H. Ade, and W. You, Energy Environ. Sci., 6, 316 (2013).

18. C. Cabanetos, A. E. Labban, J. A. Bartelt, J. D. Douglas, W. R. Mateker, J. M. J. Fréchet, M. D. McGehee, and P. M. Beaujuge, J. Am. Chem. Soc., 135, 4656 (2013).

19. I. Osaka and K. Takimiya, Polymers, 59, 1 (2015).

20. I. Osaka, M. Saito, T. Koganezawa, and K. Takimiya, Adv. Mater, 26, 331 (2014).

21. I. Osaka, G. Sauvé, R. Zhang, T. Kowalewski, and R. D. McCullough, $A d v$. Mater., 19, 4160 (2007).

22. I. Osaka, R. Zhang, G. Sauvé, D.-M. Smilgies, T. Kowalewski, and R. D. McCullough, J. Am. Chem. Soc., 131, 2521 (2009).

23. I. Osaka, R. Zhang, J. Liu, D. M. Smilgies, T. Kowalewski, and R. D. McCullough, Chem. Mater, 22, 4191 (2010).
24. J. Peet, L. Wen, P. Byrne, S. Rodman, K. Forberich, Y. Shao, N. Drolet, R. Gaudiana, G. Dennler, and D. Waller, Appl. Phys. Lett., 98, 043301 (2011).

25. M. Zhang, X. Guo, and Y. Li, Adv. Eng. Mater, 1, 557 (2011).

26. S. Subramaniyan, H. Xin, F. S. Kim, S. Shoaee, J. R. Durrant, and S. A. Jenekhe, Adv. Eng. Mater, 1, 854 (2011)

27. Q. Shi, H. Fan, Y. Liu, W. Hu, Y. Li, and X. Zhan, J. Phys. Chem. C, 114, 16843 (2010).

28. M. Yang, B. Peng, B. Liu, Y. Zou, K. Zhou, Y. He, C. Pan, and Y. Li, J. Phys. Chem. C, 114, 17989 (2010).

29. L. Huo, X. Guo, S. Zhang, Y. Li, and J. Hou, Macromolecules, 44, 4035 (2011).

30. S.-K. Lee, J. M. Cho, Y. Goo, W. S. Shin, J.-C. Lee, W.-H. Lee, I.-N. Kang, H.-K. Shim, and S.-J. Moon, Chem. Commun., 47, 1791 (2011).

31. M. Saito, I. Osaka, T. Koganezawa, and K. Takimiya, Heteroat. Chem., 25, 556 (2014).

32. M. Saito, I. Osaka, Y. Suzuki, K. Takimiya, T. Olabe, S. Ikeda, and T. Asano, Sci. Rep., 5, 14202 (2015).

33. X. Guo, J. Quinn, Z. Chen, H. Usta, Y. Zheng, Y. Xia, J. W. Hennek, R. P. Ortiz, T. J. Marks, and A. Facchetti, J. Am. Chem. Soc., 135, 1986 (2013).

34. J. T. Rogers, K. Schmidt, M. F. Toney, E. J. Kramer, and G. Bazan, Adv. Mater, 23, 2284 (2011). 